\title{
Direct and Mediated Associations among Audit Quality, Earnings Quality, and Share Price: The Case of Jordan
}

Submitted 11/03/20, $1^{\text {st }}$ revision 18/05/20, $2^{\text {nd }}$ revision 17/07/20, accepted 15/08/20

\section{Abstract:}

\author{
Malik Abu Afifa*1, Fares Alsufy ${ }^{2}$, and Ahmad Abdallah ${ }^{3}$
}

Purpose: The current study aims to investigate the relationship between audit quality and the share price in Jordan as a developing market. Moreover, it also uses the role of earnings quality as a mediator factor in the study model.

Design/Approach/Methodology: The study sample is comprised of all Jordanian industrial public shareholding companies listed in Amman Stock Exchange during the years 2010 to 2018. Therefore, this study uses a panel data analysis on financial disclosures.

Findings: The study concluded that a high audit quality and a high earnings quality separately increase the share price. The earnings quality partially mediates the relationship between audit quality and the share price. It was also found that a high audit quality does not improve earnings quality of the targeted companies.

Practical Implication: The findings can be used in efforts to: (i) identify the level of Jordanian market control over audit quality and earnings quality with evidence; (ii) provide more explanations on the importance of audit quality and quality of financial information in the biasness environment; (iii) the results of the this study will be more important for the investors, management, decisions makers, policy makers, and other interested parties; (iv) the findings of the study help the policy makers to adopt good regulations to improve the transparency in reporting the financial information that affects the share price.

Originality/Value: The study is an original study and it adds to scholarly debate on effect of audit quality and earnings quality on the share price in Jordan as a developing market. It also uses the role of earnings quality as a mediator factor in the relationship between audit quality and the share price.

Keywords: Earnings management, earnings quality, audit quality, share price.

JEL codes: M21, M40, M41, N20.

Paper Type: Research Article.

\footnotetext{
${ }^{l}$ Corresponding author - Faculty of Business, Department of Accounting, Al-Zaytoonah

University of Jordan, Amman, Jordan. E-mail: M.abuafifa@zuj.edu.jo

${ }^{2}$ Faculty of Business, Department of Accounting, Isra University, Amman, Jordan.

E-mail: fares.alsufy@iu.edu.jo

${ }^{3}$ Faculty of Business, Department of Accounting, Al-Zaytoonah University of Jordan, Amman, Jordan.E-mail: Ahmad.adel@zuj.edu.jo
} 


\section{Introduction}

A modern business environment witnesses rapid changes in various fields and largescale global challenges represented by the globalization of the economy and spread of information (Abdallah et al., 2015). The need for financial reporting arises originally because of the separation of ownership, management and control in the recent times of business organizations. Financial reporting is one of the primary responsibilities of the firms' management that enables them to give an account of their stewardship (Tyokoso et al., 2016). So, the role of auditor is to plan and perform audits to obtain reasonable assurance that the financial statements are free of material misstatements and to express their opinion on fair presentation of the financial statements (Christensen et al., 2016).

Many researchers (Inaam and Khamoussi, 2016) have investigated the effect of audit quality on reducing the extent of earnings management, but empirical evidence is rather inconsistent. Inaam and Khamoussi (2016) documented that audit quality has a negative relationship with real earnings management. Audit quality may help Board of Directors, stakeholders, and regulators by reducing the opportunities given to companies' directors to engage in earnings management. Zgarni et al. (2016) also noted a significant relationship between the score of auditor industry specialization and earnings management constrains as auditor industry speciality contributes to reduce the discretionary accruals as a proxy for earnings management (Larson and Resutek, 2011). Muttakin et al. (2017) found that the discretionary accruals are positively linked to business group affiliation status, and the higher audit quality reduces this link. They also discussed that audit quality can help to improve earnings quality. This view is supported by the work of Orazalin and Akhmetzhanov (2019), Leuz et al. (2003), Wysocki (2005), Latif et al. (2017), and Antonio et al. (2019).

Oroud et al. (2019) discussed the role of audit quality in the relationship between the cash flows and accruals with the share price, and they noted that cash flows and accruals have a significant relationship with the share prices. They also confirmed that audit quality has significant moderating in this relationship. High audit quality will improve the reliability of information related to financial statements, and this contributes to increase the share prices (Balsam et al., 2003; Krishnan, 2003; Khurana and Raman, 2004).

Some empirical evidence (Doyle et al., 2007; Drake et al., 2009; Alsufy et al., 2020) documented that quality of financial statements affects accruals, and a low-quality audit means a high level of mispricing. At the same time, other empirical evidence (Charitou et al., 2001; Pourheydari and Ahmadi, 2008; Penman and Yehuda, 2009) documented that the share price is significantly linked with the information related to financial statements and earnings. Wijaya (2020) examined the relationship between audit quality and firm value, and they found that audit quality has a positive relationship with firm value. The reason is that higher audit quality is expected to reduce information asymmetry, and to reduce agency costs, as well as increase firm 
value (Abdelghany, 2005; Asthana, 2014; Alsmairat et al., 2018; Ugwunta et al., 2018).

Allahkaram et al. (2017) argued that there is a significant positive relationship of auditor specialization and audit firm size with earnings sustainability, while no significant relationship between auditor tenure and earnings sustainability. The auditor specialization and big-audit firms contribute to improve investment efficiency in business firms, and thus earnings sustainability will increase. While Almarayeh $e t$ al. (2020) investigated the role of audit quality in reducing earnings management in order to improve the share market prices. They noted that auditor size and audit fees have no significant effect on earnings management.

Therefore, it can be noted that numerous studies (Charitou et al., 2001; Balsam et al., 2003; Krishnan, 2003; Khurana and Raman, 2004; Pourheydari and Ahmadi, 2008; Penman and Yehuda, 2009; Muttakin et al., 2017; Orazalin and Akhmetzhanov, 2019; Almarayeh et al., 2020; Kourtis et al., 2019) have investigated the role of audit quality in the quality of financial statements and the share price. Those studies obtained varying and inconsistent findings. As well, more of those studies provided some evidences from developed markets, and thus there are limited attempts in developing markets. Continuously, this study develops an econometric model of the direct relationship between audit quality and the share price, as new empirical evidence from Jordanian market, as an emerging market. Continually, it investigates the role of earnings quality as a mediator factor in this relationship.

According to Okolie et al. (2013) and Okolie (2014), the stakeholder theory, the agency theory, and the signalling theory suggested auditing as a tool for mitigating information asymmetries in the financial statements. The high audit quality treats information asymmetry, as well as it reduces the uncertainties in earnings, and this may improve the share price. The stakeholder theory is a theory of companies' management and business ethics that accounts for multiple constituencies affected by business entities, such as creditors, employees, local communities, suppliers, and others (Miles, 2012). This theory addresses values and morals in managing a company (Laplume et al., 2008). Agency theory is a theory that is used to resolve and explain issues in the relationship between business shareholders and their agents (company's executives) (Jensen and Meckling, 1976; Eisenhardt, 1989). Signalling theory is a theory that is used to examine communication between individuals. Mathematical models explain how signalling can contribute in companies to an evolutionarily stable strategy (Connelly et al., 2011).

Hence, our contributions from the current study exposed through: Firstly, increase the body of the knowledge about the relationship between audit quality and the share price, as well as the role of the earnings quality as a mediator factor in the relationship between audit quality and the share price. This study provides empirical evidences from Jordanian market, as an emerging market, as well as the period of this study covered nine years (2010-2018) after the last financial crisis (August 2008). Secondly, 
identifies the level of Jordanian market controlling of audit quality and earnings quality, and provides some evidences about it. This means that perceptions of audit quality and earnings quality may be improve the value of market equity in the Jordanian market. Thirdly, provides more explanations on the importance of audit quality and quality of financial information in the biasness environment. Fourthly, the findings of the current study will be more important for the investors, management, decisions makers, policy makers, and other interest parties. For example, the investors and other interested parties should adopt the deterministic and practical scenarios in order to identify which environmental factors increase the share price. The findings of this study help the policy makers on adopting good regulations to improve the transparency in reporting the financial information that affects the share price.

\section{Literature Review}

\subsection{Audit Quality}

The extent to which financial statement users can rely on an audit opinion depends on the quality of the audit performed, which is important to the stability of the capital markets. The large body of the research investigates the topic, regulators, and investors. Researchers also discussed the definition, composition, and measurement of audit quality (Bedard et al., 2010; DeFond and Zhang, 2014; Francis, 2011; Knechel et al., 2013). The Public Company Accounting Oversight Board (PCAOB) currently provides information regarding audit quality through the release of inspection reports, and the Board intends to establish and report audit quality indicators as illustrated in (PCAOB, 2012; 2013; 2014). Moreover, the PCAOB's efforts to define and measure audit quality may affect both auditors' and investors' perceptions of audit quality. DeAngelo (1981) was first who defined audit quality as the market-assessed joint probability that a given auditor discovers a breach in the client's accounting system and reports the breach.

In previous research, audit quality had the proxies of several measurements, including audit firm size, audit tenure, audit industry specialization, accrual, and so on $(\mathrm{Hu}$, 2015). Meanwhile, earnings quality had the proxies of the accrual approach (AlThuneibat et al., 2011; Francis and Wang, 2008; Siagian and Tresnaningsih, 2011; Wang et al., 2014) and earning response coefficient (Ghosh and Moon, 2005; Teoh and Wong, 1993; Zakaria and Daud, 2013).

\subsection{Earnings Quality}

Earnings quality is a key characteristic of financial reporting. It embodies the principle that financial reports should be as useful as possible to investors and other capital providers in making their resource allocation decisions (Abdelghany, 2005; Ball and Shivakumar, 2005; Lymo, 2014; Beyer et al., 2019). High-quality financial reports should improve decision-making and, thus, capital market efficiency (Chan-K et al., 2006). Earnings quality is, however, an elusive construct and people tend to 
understand it in various different ways (Dechow et al., 2010). There is no generally accepted measure, but the literature has developed a variety of proxies for earnings quality, which focus on particular attributes of what earnings quality is considered to be (Perotti and Wagenhofer, 2014). Earnings quality shows accurate and unbiased earnings information which can explain company performance (Bissessur, 2008). The advantage of earning quality is that it can be used to help make decisions (Dechow et al., 2010).

\subsection{Earnings Quality and the Share Price}

Earnings quality and its relationship with share price have emerged as an issue of interest to investors, managers, analysts and other market participants (Dichev et al., 2013; Alsufy et al., 2020). Investors consider reported earnings to be a useful tool in estimating future returns and share prices (Gregory, 2014). On the other hand, analysts are interested in how best to measure the quality of earnings so as to maximize the portfolio of investors. It is therefore difficult for analyst, managers and investors in general to ignore the role of earnings quality in resources allocation (Lipe 1990; Chan et al., 2006; Cahan et al., 2009). So, understanding the relationship between earnings quality and share price is important to the extent that good earnings quality builds confidence in the minds of existing and potential investors as well as other stakeholders (Ekoja, 2004).

Therefore, we will measure the relationship between the audit quality (IV), and the share price as (DV), and how it is improve through earnings quality (Med.V). We hypothesize that high audit quality increases the share price, high audit quality improves earnings quality, high earnings quality increases the share price, and earnings quality mediates the relationship between audit quality and the share price.

\subsection{Hypotheses Development}

Kim et al. (2015) investigated the monitoring role of high-quality auditors defined as office-level industry specialists; they found that the market value of cash increases significantly when the client changes its auditor to a joint industry specialist. Some other studies (Teoh and Wong, 1993; Heninger, 2001; Balsam et al., 2003) have attempted to establish a more or less distinct relationship between audit quality and share prices of a company, and have tried to show the impact of this relationship on the quality of the earnings reported by quoted companies in many countries. The majority of the studies has seemingly contradictory and inconsistent results. Based on above, the first hypothesis was formulated as:

First Hypothesis: High audit quality increases the share price.

The current study measured audit quality by three components, namely auditor size, audit specialization and audit tenure. Previous studies, such as Sumiadji et al. (2019) found audit firm size and audit tenure have an impact on earnings quality, and at the 
same time, they found audit specialization has no impact on earnings quality. Moreover, some other studies, like Tyokoso et al. (2016) found that there are positive association between audit size, audit specialization and negative association with earnings quality. A research conducted by Zakaria and Daud (2013) also found that the Big 4 auditors have a significant and positive impact on earnings response coefficient (ERC). Based on the previous research results and explanation, the second hypothesis was formulated as:

Second Hypothesis: High audit quality improves earnings quality.

Few studies related to earnings quality with share price have also been documented in the literature. Deakin and Konzelmann (2004) and Jiang et al. (2008) focused on either market-based attributes or accounting-based attributes. This approach is considered inadequate in the sense that ignoring either category of the attributes in a study on share prices would not be able to capture the real effect of the different measures of the properties. Accordance to previous studies the third hypothesis has been formulated as follows:

Third Hypothesis: High earnings quality increases the share price.

Accordance to the above hypotheses, and in order to achieve the study objectives, the fourth hypothesis is formulated as following to link and measure all study variables:

Fourth Hypothesis: Earnings quality mediates the relationship between audit quality and the share price.

\section{Methodology}

The population of this study includes all Jordanian public shareholding companies, which are listed in the Amman Stock Exchange (ASE) from 2010 to 2018. The study sample consists of all Jordanian industrial public shareholding companies. There are 52 Jordanian industrial public shareholding companies listed in ASE up to 2018. Official reports from government entities, such as Central Bank of Jordan at the end of the year 2019 documented that Jordanian industrial sector is one of the most important sectors in Jordanian economy as it contributes about $25.2 \%$ of the Gross Domestic Product (GDP) amounted to around 3.25 billion JDs.

This study uses a panel data analysis based on the financial disclosures related to the Jordanian industrial public shareholding companies during the study period. The study model includes audit quality (AQ) as an independent variable, earnings quality (EQ) as a mediate variable, and the share price of industrial public shareholding companies as a dependent variable. AQ is measured by three components namely auditor size, audit specialization and audit tenure (Sumiadji et al., 2019; Alzoubi, 2016; Francis and Wang, 2008; Wang et al., 2014; Al-Thuneibat et al., 2011; Davis et al., 2000; Gul et al., 2009; Myers-J et al., 2003; Balsam et al., 2003). These components, as 
dichotomous variables, and assume that Big four audit companies (Deloitte, Ernst \& Young-EY, KPMG, and PWC) are of higher quality than non-big four audit companies, as well as auditors (audit companies) with industry specialization are of higher quality than non where the auditors can work more effectively (Sumiadji et al., 2019), and a longer audit company tenure will reduce the level of auditor's independence (Sumiadji et al., 2019; Al-Thuneibat et al., 2011; Davis et al., 2000; Johnson et al., 2002). Thereby, the study measures AQ components based on disclosures of targeted companies as follows:

- Auditor size (ASI): A dummy variable of (1) if the industrial public shareholding company is audited by big four audit companies (Deloitte, Ernst \& Young-EY, KPMG, and PWC), and (0) otherwise (Alzoubi, 2016; Sumiadji et al., 2019).

- Audit specialization (ASP): A dummy variable, (1) for audit companies which have industry specialization, and (0) otherwise (Solomon et al., 1999; Zhou and Elder, 2004; Sumiadji et al., 2019).

- Audit tenure (ATE): A dummy variable, (1) if the industrial public shareholding company is audited by same audit company for more than three years, and (0) otherwise (Johnson et al., 2002; Al-Thuneibat et al., 2011; Sumiadji et al., 2019).

EQ in this study is expressed as a ratio. It measured by the operating cash flow to total assets ratio (OCFTAi.t) for the company (i) for the period (t), to the net income to total assets ratio (NITAi.t) for the company i for the period $t$, as a following equation: (Abu Ali et al., 2011; Alsufy et al., 2020):

$$
\text { EQi. } \mathrm{t}=\frac{\text { OCFTAi.t }}{\text { NITAi.t }}
$$

The share price (SPi.t) is the shares prices of industrial public shareholding company (i) at the end of each year (t) during the study period (2010 to 2018) (Warrad, 2017). However, the company size of industrial public shareholding is a control variable in this study. It is a dummy variable, [1] (a small-sized) if the total assets of company is less than 20 million JD, [2] (a med-sized) if total assets is ranged 20 to less than 40 million JD, [3] (a large-sized) if total assets is ranged 40 to less than 60 million JD, and finally [4] (a very large-sized) if the total assets otherwise.

Table (1) shows the distribution of industrial public shareholding companies based on the previous four sizes, and the Table indicates that $72.5 \%$ of industrial public shareholding companies were their total assets less than 40 million JD, and $27.5 \%$ of the targeted companies were their total assets 40 million JD and more. 
Table 1. Companies' sizes

\begin{tabular}{l|lll}
\hline \multicolumn{1}{l}{ Variables } & $\begin{array}{l}\text { Frequenc } \\
\mathbf{y}\end{array}$ & $\begin{array}{l}\text { Percent } \\
\mathbf{\%}\end{array}$ & $\begin{array}{l}\text { Cumulative } \\
\text { Percent \% }\end{array}$ \\
\hline Less than 20 million JD & 268 & 57.3 & 57.3 \\
$\geq 20$ million JD to less than 40 million JD & 71 & 15.2 & 72.5 \\
$\geq 40$ million JD to less than 60 million JD & 33 & 7.0 & 79.5 \\
60 million JD and more & 96 & 20.5 & 100 \\
\hline
\end{tabular}

Source: Own study.

\section{Data Analysis and Findings}

Initially, the study relied on deleting irregular values from the study data, and this is in order to improve reliability and validity of the data for testing. Moreover, the multicollinearity tests had used in this study in order to identify if the data of the study suffer from any econometric problems (Baltagi et al., 2010; Gujarati and Porter, 2009; Baltagi, 2008). This study checked the multicollinearity via Pearson correlation, and then the Variance Inflation Factor (VIF) and the inverse VIF (tolerance (TOL, 1/VIF)). Table 2 indicates the Pearson correlation (Beta) between the independent, mediator and control variables of the study, respectively. The multicollinearity issue appears when the correlation value (Beta) between two variables is more than 0.8 (Gujarati, 2003). The Pearson correlation values between the study variables are less than 0.80 , therefore the regression models of the current study do not suffer (is a fit) from the multicollinearity issue.

Table 2. Pearson Correlation (Beta)

\begin{tabular}{l|lllll}
\hline Variables & ASI & ASP & ATE & EQ & Size \\
\hline ASI & $\mathbf{1 . 0 0 0}$ & & & & \\
ASP & 0.302 & $\mathbf{1 . 0 0 0}$ & & & \\
ATE & -0.011 & -0.300 & $\mathbf{1 . 0 0 0}$ & & \\
EQ & -0.011 & -0.032 & -0.051 & $\mathbf{1 . 0 0 0}$ & \\
Size (Ln total assets) & 0.114 & -0.159 & 0.123 & 0.011 & $\mathbf{1 . 0 0 0}$ \\
\hline
\end{tabular}

Source: Own study.

Then, Table 3 indicates the VIF and TOL values for the independent, mediator and control variables. The result proves that the multicollinearity issue does not exist, and thereby the study model is a fit model. This is because the VIF value for all variables is less than 10 and the TOL value for all variables is more than 10\% (Gujarati, 2003). 
Table 3. Testing for multicolleniarity

\begin{tabular}{l|ll}
\hline Variables & VIF & 1/VIF \\
\hline ASI & 1.121 & $\mathbf{0 . 8 9 2}$ \\
ASP & 1.165 & 0.858 \\
ATE & 1.066 & 0.938 \\
EQ & 1.012 & 0.988 \\
Size (Ln total assets) & 1.060 & 0.943 \\
\hline
\end{tabular}

Source: Own study.

Table 4 presents descriptive analysis (minimum and maximum value, arithmetic average, and standard deviation) for the study variables. The arithmetic average value for ASI is $0.320(\mathrm{SD}=0.467)$, and this means that $32.0 \%$ of the industrial public shareholding companies audited by big four audit companies (Deloitte, Ernst \& Young-EY, KPMG, and PWC) during the study period (2010 to 2018). Then, the arithmetic average value for ASP is 0.041 ( $\mathrm{SD}=0.199)$, in other words, $95.9 \%$ of audit companies practiced auditing duties for the industrial public shareholding companies not industry specialization.

The arithmetic average value for ATE is 0.877 ( $\mathrm{SD}=0.329$ ). This means that $87.7 \%$ of the industrial public shareholding companies audited by same audit company for more than three years. Next, the arithmetic average of EQ between industrial public shareholding companies is $0.861(\mathrm{SD}=2.891)$. The arithmetic average for $\mathrm{SP}$ is JD 2.345 during the study period, and the maximum value of SP is JD 46.51. Also, the arithmetic average for total assets for industrial public shareholding companies in Jordan is JD 64,678,633.

Table 4. Descriptive Analysis

\begin{tabular}{l|llll}
\hline \multicolumn{1}{l}{ Variables } & Minimum & Maximum & $\begin{array}{l}\text { Arithmetic } \\
\text { average }\end{array}$ & $\begin{array}{l}\text { Standard } \\
\text { deviations (SD) }\end{array}$ \\
\hline ASI & 0 & 1 & 0.320 & 0.467 \\
ASP & 0 & 1 & 0.041 & 0.199 \\
ATE & 0 & 1 & 0.877 & 0.329 \\
EQ & -14.14 & 13.25 & 0.861 & 2.891 \\
SP (JD) & 0.13 & 46.51 & 2.345 & 4.367 \\
Total assets (JD) & 320,140 & $1,211,466,000$ & $64,678,633$ & $186,444,429$ \\
\hline
\end{tabular}

Source: Own study.

The study model testing by the linear regression test, using the correcting regression with Driscoll-Kraay standard errors method. The following paragraphs explain the results of the liner regression test for each hypothesis.

First Hypothesis: High audit quality increases the share price

Table 5 indicates the results of this hypothesis. Results indicate that the first hypothesis model is a fit at a significant level of the F-statistic $\left(11.860^{* * *}\right)$. The 
independent variable (AQ) in the model explain 0.114 (Adjusted $\mathrm{R}^{2}=11.4 \%$ ) of the variations in SP. The consistent term (_Cons) of this model is positively significant $(\mathrm{Beta}=0.354)$ at $\mathrm{p}$-value $<0.01$. In other words, high AQ positively increases $\mathrm{SP}$, and thus the first hypothesis is accepted.

Table 5. The regression result of the first hypothesis

\begin{tabular}{llll}
\hline \multirow{2}{*}{ Variables } & \multicolumn{3}{l}{ SPit $=\alpha+\beta_{1}$ ASI $_{i t}+\beta_{2} A S P_{i t}+\beta_{2} A T E_{i t}+\beta_{2}$ size $_{i t}+\left(\varepsilon_{i}+v_{i t}\right)$} \\
\cline { 2 - 4 } & Coefficients & $(\boldsymbol{t}$-static $)$ & Sig. \\
\hline Con- & -0.084 & -0.198 & 0.843 \\
Size & 1.262 & 6.848 & $0.000^{* * *}$ \\
\hline Con- & 0.024 & 0.032 & 0.975 \\
ASI & 0.437 & 0.866 & 0.387 \\
ASP & -0.181 & -0.132 & 0.895 \\
ATE & -0.238 & -0.329 & 0.743 \\
Size (Ln total assets $)$ & 1.242 & 6.538 & $0.000^{* * *}$ \\
\hline Adjusted $R$ Square & 0.114 & & \\
(F-value) & $11.863^{* * *}$ & &
\end{tabular}

Note: $*, * *, * * *=\mathrm{p}$-value $<.10, .05, .01$.

Source: Own study.

Second Hypothesis: High audit quality improves earnings quality

The results of the second hypothesis "high audit quality improves earnings quality" are shown in Table 6 . These results indicate that the second hypothesis does not fit at a significant level of the F-statistic (0.437), and thus the second hypothesis is rejected. This means that no effect of AQ in improving EQ of industrial public shareholding companies because AQ could be one possible tool to enhance financial reporting quality, but it is not improving EQ because the audit tasks are after extracting the business results and identify the business earnings.

Table 6. The regression result of the second hypothesis - model

\begin{tabular}{llll}
\hline \multirow{2}{*}{ Variables } & \multicolumn{3}{l}{ EQit $=\alpha+\beta_{1} A S I_{i t}+\beta_{2} A S P_{i t}+\beta_{2} A T E_{i t}+\beta_{2}$ size $_{i t}+\left(\varepsilon_{i}+v_{i t}\right)$} \\
\cline { 2 - 4 } & Coefficients & $($ t-static $)$ & Sig. \\
\hline Con- & 0.768 & 2.586 & $0.010^{* *}$ \\
Size & 0.039 & 0.296 & 0.767 \\
\hline Con- & 0.024 & 0.032 & $0.013^{* *}$ \\
ASI & 0.437 & 0.866 & 0.974 \\
ASP & -0.181 & -0.132 & 0.419 \\
ATE & -0.238 & -0.329 & 0.242 \\
Size (Ln total assets $)$ & 1.242 & 6.538 & 0.761 \\
\hline Adjusted $R$ Square & 0.007 & & \\
(F-value) & 0.437 & &
\end{tabular}

Note: $*, * *, * * *$ p-value $<.10, .05, .01$.

Source: Own study. 
Third Hypothesis: High earnings quality increases the share price

Moreover, the results of third hypothesis test reported in Table 7. Results presents that the model of the hypothesis is a fit at a significant level of the F-statistic (26.813***), and thus this hypothesis is accepted. EQ in this model explain 0.141 (Adjusted $\mathrm{R}^{2}=$ $14.1 \%$ ) of the variations in SP. The consistent term (_Cons) of this model is positively significant $(B e t a=0.382)$ at $\mathrm{p}$-value $<0.01$. Therefore, high EQ affects in increase SP.

Table 7. The regression result of the third hypothesis

\begin{tabular}{llll}
\hline \multirow{2}{*}{ Variables } & \multicolumn{3}{l}{ SPit $=\alpha+\beta_{1} E Q_{i t}+\beta_{2}$ size $e_{i t}+\left(\varepsilon_{i}+v_{i t}\right)$} \\
\cline { 2 - 4 } & Coefficients & $(\boldsymbol{t}$-static $)$ & Sig. \\
\hline Con- & -0.256 & -0.584 & 0.560 \\
Size & 1.437 & 7.328 & $0.000^{* * * *}$ \\
\hline Con- & -0.277 & -0.622 & 0.535 \\
EQ & 0.023 & 0.279 & 0.781 \\
Size & 1.437 & 7.317 & $0.000^{* * *}$ \\
\hline Adjusted $R$ Square & .141 & & \\
$($ F-value $)$ & $26.813^{* * *}$ & &
\end{tabular}

Note: $* * *, * * *=\mathrm{p}$-value $<.10, .05, .01$.

Source: Own study.

Fourth Hypothesis: Earnings quality mediates the relationship between audit quality and the share price

Table 8 indicates the results of the fourth hypothesis "Earnings quality mediates the relationship between audit quality and the share price". Results indicate that the model of the hypothesis is a fit at a significant level of the F-statistic $\left(10.466^{* * *}\right)$, and thereby EQ mediates the relationship between AQ and the SP, but not full mediate. AQ with EQ in this model explain 0.133 (Adjusted $\mathrm{R}^{2}=13.3 \%$ ) of the variations in SP. The consistent term (_Cons) of this model is positively significant (Beta $=0.383$ ) at $\mathrm{p}$-value $<0.01$. Thus, the fourth hypothesis is accepted.

Table 8. The regression result of the fourth hypothesis

\begin{tabular}{|c|c|c|c|}
\hline \multirow[t]{2}{*}{ Variables } & \multicolumn{3}{|c|}{$\begin{array}{l}\text { SPit }=\alpha+\beta_{1} A S I_{i t}+\beta_{2} A S P_{i t}+\beta_{2} A T E_{i t}+\beta_{2} E Q_{i t}+\beta_{2} \text { size }_{i t} \\
+\left(\varepsilon_{i}+v_{i t}\right)\end{array}$} \\
\hline & Coefficients & (t-static) & Sig. \\
\hline Con- & -0.100 & -0.123 & $0.013^{* *}$ \\
\hline ASI & 0.436 & 0.804 & 0.422 \\
\hline ASP & -0.216 & -0.154 & 0.878 \\
\hline ATE & -0.308 & -0.400 & 0.689 \\
\hline EQ & 0.021 & 0.251 & 0.802 \\
\hline Size (Ln total assets) & 1.417 & 6.879 & $0.000^{* * * *}$ \\
\hline $\begin{array}{l}\text { Adjusted R Square } \\
\text { (F-value) }\end{array}$ & $\begin{array}{l}0.133 \\
10.466\end{array}$ & & \\
\hline
\end{tabular}

Note: $*, * * * * *=$ p-value $<.10, .05, .01$.

Source: Own study. 


\section{Conclusions and Discussions}

The findings of the current study indicate that high audit quality increases the share price of Jordanian public shareholding companies. This means that audit quality positively increases the market value of the share, and it also indicates that audit quality explains $(11.4 \%)$ of the variance of the market value of the share. This is because high audit quality will improve the quality of financial information related to financial disclosures, and improve the investors' confidence in these companies, and then the share price increases. Audit quality contributes to reduce information asymmetry, and reduce agency costs, and this will increase the firm value (Abdelghany, 2005; Alsmairat et al., 2018; Asthana, 2014). This finding also matches with the work of Almarayeh et al. (2020), Zgarni et al. (2016), Balsam et al. (2003), Krishnan (2003), and Khurana and Raman (2004), while it does not match with the findings of Allahkaram et al. (2017), where they noted no significant relationship between auditor tenure and earnings sustainability.

Furthermore, the current study indicates that high audit quality not improves earnings quality, and this finding not matches with the work of Muttakin et al. (2017) and Orazalin and Akhmetzhanov (2019). This result consists with the work of Almarayeh et al. (2020). They documented that earnings management not affected by audit quality, especially auditor size and audit fees. This may be referred to the fact that the audit tasks begin after extracting the business results and business earnings.

Additionally, the findings show that high earnings quality increases the share price. Larson and Resutek (2011) documented that earnings quality positively affects market return and then the share price. Continually with this finding, Leuz et al. (2003), Wysocki (2005), DeFond et al. (2007), Dechow et al. (2010), Latif et al. (2017), Antonio et al. (2019) and Alsufy et al. (2020) noted that earnings quality has a positive effect on investor protection, and this will improve the share price. While this finding does not matches with the work of Wijesinghea and Kehelwalatennab (2017). They noted that earnings quality has not effect on manufacturing companies' shares returns, and then it does not support their share price.

The findings point out that earnings quality mediates the relationship between audit quality and the share price. This matches with the work of Balsam et al. (2003), Krishnan (2003), Khurana and Raman (2004), and Islam et al. (2019). They documented that high audit quality with the improvement of the reliability of information related to financial statements for the users (shareholders and investors) by earnings quality will improve the share price. Also, this is supported by theoretical framework based on the stakeholder theory, the agency theory, and the signalling theory (Okolie et al., 2013; Okolie, 2014). 


\section{Study Recommendations and Future Research}

Based on the findings concluded in this study, the researchers recommend to companies, especially Jordanian industrial public shareholding companies, should be urged to address the obstacles that limit the effect of audit quality and earnings quality on the reliability of information related to financial statements in order to reduce information asymmetry and improve the investors' confidence, and then the share price increases. This study also recommends researchers to investigate the effect of audit quality and earnings quality on earnings management. Future research could also determine factors that affect the share price, to know the best factors to improve the share price, especially in emerging markets.

\section{References:}

Abdallah, A., Mssadeh, A., Hussein, O. 2015. Measuring the Impact of Business Risks on the Quality of the Auditing Process. Review of Integrative Business and Economic Research, 4(2), 171-181.

Abdelghany, K. 2005. Measuring the Quality of Earnings. Managerial Auditing Journal, 20, 1001-1015. https://doi.org/10.1108/02686900510625334.

Allahkaram, S., Shahrokh, B., Amin, A. 2017. Investigating the Effect of Audit Quality on Sustainability of Earnings (Case study: a Comparison between FinanciallyDistressed Companies and the Rest of Companies in Tehran Stock Exchange). Journal of accounting knowledge and management auditing, 5(20), 47-59.

Almarayeh, T.S., Aibar-Guzman, B., Abdullatif, M. 2020. Does audit quality influence earnings management in emerging markets? Evidence from Jordan. Revista De Contabilidad - Spanish Accounting Review, 23(1), 64-74. https://doi.org/10.6018/rcsar.365091.

Alsmairat, Y.Y., Yusoff, W.S., Fairuz, M., Saleh, M., Norida. B. 2018. International Diversification, Audit Quality and Firm Value of Jordanian Public Listed Firm. Academy of Accounting and Financial Studies Journal, 22, 1-7.

Alsufy, F., Abu Afifa, M., Soda, M.Z. 2020. Mediating Effects of Liquidity in the Relationship between Earnings Quality and Market Value of the Share Price: Evidence from Jordan. Review of Applied Socio- Economic Research, 19(1), 17-32.

Al-Thuneibat, A.A., Al-Issa, R.T.I., Baker, A.R.A. 2011. Do audit tenure and firm size contribute to audit quality? Empirical evidence from Jordan. Managerial Auditing Journal, 26(4), 317-334. https://doi.org/10.1108/02686901111124648.

Antonio, M., Laela, S., Darmawan, R. 2019. Corporate Governance, Earnings Quality and Market Response: Comparison of Islamic and Non-Islamic Stock in the Indonesian Capital Market. Academy of Accounting and Financial Studies Journal, 23(1), 1-22.

Asthana, S. 2014. Abnormal audit delays, earnings quality and firm value in the USA. Journal of Financial Reporting and Accounting, 12(1), 21-44. doi 10.1108/JFRA09-2011-0009.

Ball, R., Shivakumar, L. 2005. Earnings Quality in UK Private Firms: Comparative Loss Recognition Timeliness. Journal of Accounting and Economics, 39(1), 83-128. https://doi.org/10.1016/j.jacceco.2004.04.001.

Balsam, S., Krishnan, J., Yang, J. 2003. Auditor industry specialization and earnings quality. Auditing: A Journal of Practice and Theory, 22(2), 71-97. https://doi.org/10.2308/aud.2003.22.2.71. 
Bedard, J.C., Johnstone, K.M., Smith, E.F. 2010. Audit quality indicators: A status update on possible public disclosures and insights from audit practice. Current Issues in Auditing, 4(1), 12-19. DOI: 10.2308/ciia.2010.4.1.C12.

Beyer, A., Guttman, I., Marinovic, I. 2019. Earnings Management and Earnings Quality: Theory and Evidence. The Accounting Review, 94(4), 77-101.

Bissessur, S.W. 2008. Earnings quality and earnings management: The role of accounting accruals. PhD thesis, University of Amsterdam, Rotterdam.

Cahan, F.S., Emmanuel, D., Sun, J. 2009. The effect of earnings quality and country level institutions on the value relevance of earnings. Review of Quantitative Finance Accounting, 33, 371-391. https://doi.org/10.1007/s11156-009-0117-z.

Chan, K., Chan, L.K.C., Jegadeesh, N., Lakonishok, J. 2006. Earnings Quality and Stock Returns. The Journal of Business, 79(3), 1041-1082.

Charitou, A., Clubb, C., Andreou, A. 2001. The effect of earnings permanence, growth and firm size on the usefulness of cash flows and earnings in explaining security returns: empirical evidence for the UK. Journal of Business Finance and Accounting, 28(56), 563-594. https://doi.org/10.1111/1468-5957.00385.

Christensen, B.E., Glover, S.M., Omer, T.C., Shelley, M. 2016. Understanding Audit Quality: Insights from Audit Professionals and Investors. Contemporary Accounting Research, 33(4), 1648-1684. https://dx.doi.org/10.2139/ssrn.2358163.

Connelly, B.L., Certo, S.T., Ireland, R.D., Reutzel, C. 2011. Signaling Theory: A Review and Assessment. Journal of Management, 37(1), 3967. doi:10.1177/0149206310388419.

Deakin, S., Konzelmann, S.J. 2004. Learning from Enron. Corporate Governance, 12(2), 134-142.

DeAngelo, L.E. 1981. Auditor size and audit quality. Journal of Accounting and Economics, 3(3), 183-199. https://doi.org/10.1016/0165-4101(81)90002-1.

Dechow, P., Ge, W., Schrand, C. 2010. Understanding earnings quality: A review of the proxies, their determinants and their consequences. Journal of Accounting and Economics, 50(2-3), 344-401. https://doi.org/10.1016/j.jacceco.2010.09.001.

Dechow, P.M., Ge, W., Schrand, C. 2010. Understanding earnings quality: A review of the proxies, their determinants and their consequences. Journal of Accounting and Economics, 50(2-3), 344-401.

DeFond, M.L., Zhang, J. 2014. A review of archival auditing research. Journal of Accounting and Economics, 58(2-3), 275-326. https://doi.org/10.1016/j.jacceco.2014.09.002.

Dichev, I.D., Graham, J.R., Harvey, C.R., Rajgopal, S. 2013. Earnings Quality: Evidence from the Field. Journal of Accounting and Economics, 56(2-3), 1-33.

Doyle, J.T., Ge, W., McVay, S.E. 2007. Accruals quality and internal control over financial reporting. The Accounting Review, 82(5), 1141-1170. https://doi.org/10.2308/accr.2007.82.5.1141.

Drake, M.S., Myers, J.N., Myers, L.A. 2009. Disclosure quality and the mispricing of accruals and cash flow. Journal of Accounting, Auditing, and Finance, 24(3), 357384. https://doi.org/10.1177/0148558X0902400303.

Eisenhardt, K.M. 1989. Agency Theory: An Assessment and Review. The Academy of Management Review, 14(1), 57-74. https://www.jstor.org/stable/258191.

Ekoja, B.E. 2004. A cross-sectional analysis of discretionary accruals. Nigerian Journal of Accounting Research, 2, 36-44.

Francis, J.R., Wang, D. 2008. The joint effect of investor protection and big 4 audits on earnings quality around the world. Contemporary Accounting Research, 25(1), 157191. https://doi.org/10.1506/car.25.1.6. 
Francis, J.R. 2011. A framework for understanding and researching audit quality. Auditing: A Journal of Practice and Theory, 30(2), 125-152. https://doi.org/10.2308/ajpt50006.

Ghosh, A., Moon, D. 2005. Auditor Tenure and Perception of Audit Quality. The Accounting Review, 80(2), 585-612. https://doi.org/10.2308/accr.2005.80.2.585.

Heninger, W.G. 2001. The association between auditor litigation and abnormal accruals, American Accounting Association. The Accounting Review, 76(1), 111-126. https://www.jstor.org/stable/3068847.

Hu, D. 2015. Audit Quality and Measurement: Towards a Comprehensive Understanding. Academy of Accounting and Financial Studies Journal, 19(1), 209-222.

Inaam, Z., Khamoussi, H. 2016. Audit committee effectiveness, audit quality and earnings management: a meta-analysis. International Journal of Law and Management, 58 (2), 179-196. https://doi.org/10.1108/IJLMA-01-2015-0006.

Jensen, M.C., Meckling, W.H. 1976. Theory of the firm: Managerial behavior, agency costs and ownership structure. Journal of Financial Economics, 3(4), 305-360. https://www.sfu.ca/ wainwrig/Econ400/jensen-meckling.pdf.

Jiang W., Lee, P., Anandarajan, A. 2008. The association between corporate governance and earnings quality: Further evidence using the GOV-Score. Advances in Accounting, 24(2), 191-201. https://doi.org/10.1016/j.adiac.2008.08.011.

Khurana, I., Raman, K.K. 2004. Are Big 4 audits in ASEAN countries of higher quality than non-Big 4 audits? Asia Pacific Journal of Accounting and Economics, 11(2), 139165. https://doi.org/10.1080/16081625.2004.10510640.

Kim, J., Lee, J., Park, J. 2015. Audit Quality and the Market Value of Cash Holdings: The Case of Office-Level Auditor Industry Specialization. Auditing: A Journal of Practice \& Theory, 34(2), 27-57.

Knechel, W.R., Krishnan, G.V., Pevzner, M.B., Shefchik, L., Velury, U. 2013. Audit quality: Insights from the academic literature. Auditing: A Journal of Practice and Theory, 32(1), 385-421. https://doi.org/10.2308/ajpt-50350.

Kourtis, E., Kourtis, G., Curtis, P. 2019. An Integrated Financial Ratio Analysis as a Navigation Compass through the Fraudulent Reporting Conundrum: A Case Study. International Journal of Finance, Insurance and Risk Management, 9(1-2), 3-20. DOI: $10.35808 /$ ijfirm/187.

Krishnan, G.V. 2003. Auditor quality and the pricing of discretionary accruals. Auditing: A Journal of Practice \& Theory, 22(1), 109-126. https://doi.org/10.2308/aud.2003.22.1.109.

Laplume, A., Sonpar, K., Litz, R. 2008. Stakeholder Theory: Reviewing a Theory That Moves Us. Journal of Management, 34(6), 11521189. doi:10.1177/0149206308324322.

Larson, C., Resutek, R. 2011. How does earnings quality affect the equity market? An alternative measure and a new perspective. Paper presented in Accounting Seminars, Columbia.

Latif, K., Bhatti, A., Raheman, A. 2017. Earnings Quality: A Missing Link between Corporate Governance and Firm Value. Business \& Economic Review, 9(2), 255 280.

Leuz, C., Nanda, D., Wysocki, P. 2003. Earnings management and institutional factors: an international comparison. Journal of Financial Economics, 69(3), 505-527.

Lipe, R. 1990. The relation between stock returns and accounting earnings given alternative information. American Accounting Association, The Accounting Review, 65(1), 4971. ISSN 0001-4826, ZDB-ID 210224-9. 
Lymo, G.D. 2014. Assessing the measures of quality of earnings: evidence from India. European Journal of Accounting Auditing and Finance Research, 2(6), 17-28.

Miles, S. 2012. Stakeholders: essentially contested or just confused? Journal of Business Ethics, 108(3), 285-298. doi:10.1007/s10551-011-1090-8.

Muttakin, M., Khan, A., Mihret, D. 2017. Business group affiliation, earnings management and audit quality: evidence from Bangladesh. Managerial Auditing Journal, 32 (4/5), 427-444. https://doi.org/10.1108/MAJ-01-2016-1310.

Okolie, A.O. 2014. Audit quality and earnings response coefficients of quoted companies in Nigeria. Journal of Applied Finance \& Banking, 4(2), 139-161.

Okolie, A.O., Izedonmi, F.O.I., Enofe, A.O. 2013. Audit quality and accrual-based earnings management of quoted companies in Nigeria. IOSR Journal of Economics and Finance (IOSR-JEF), 2(2), 7-16. https://doi.org/10.9790/5933-0220716.

Orazalin, N., Akhmetzhanov, R. 2019. Earnings management, audit quality, and cost of debt: evidence from a Central Asian economy. Managerial Auditing Journal, 34(6), 696721. https://doi.org/10.1108/MAJ-12-2017-1730.

Oroud, Y., Islam, A., Ahmad, T., Ghazalat, A. 2019. Does Audit Quality Moderate the Relationship between Accounting Information and the Share Price? Evidence from Jordan. International Business Research, 12(3), 58-65.

Penman, S.H., Yehuda, N. 2009. The pricing of earnings and cash flows and the affirmation of accrual accounting. Review of Accounting Studies, 14(4), 453-479. https://doi.org/10.1007/s11142-009-9109-4.

Perotti, P., Wagenhofer, A. 2014. Earnings Quality Measures and Excess Returns. Journal of Business Finance \& Accounting, 41(5-6), 545-571. http://dx.doi.org/10.1111/jbfa.12071.

Pourheydari, O., Ahmadi, S.A. 2008. Accruals and cash flows in equity valuation: Iranian case. Middle Eastern Finance and Economics, 2, 5-15.

Public Company Accounting Oversight Board (PCAOB). 2012. Strategic Plan: Improving Relevance and Quality of the Audit for the Protection and Benefit of Investors, 2012-2016. November 30. Available online at: https://pcaobus.org/About/Administration/Documents/Strategic\%20Plans/20122016.pdf.

Public Company Accounting Oversight Board (PCAOB). 2013. Standing Advisory Group meeting briefing paper, Audit Quality Indicators. May 15-16. Available online at: http://pcaobus.org/News/Events/Documents/05152013_SAGMeeting/Audit_Quality _Indicators.pdf, retrieved 11/6/2013.

Public Company Accounting Oversight Board (PCAOB). 2014. Session on Audit Quality Indicators. 2014 PCAOB/AAA Annual Meeting memo and meeting materials, April 17. Available online at: https://pcaobus.org/About/Administration/Documents/Annual\%20Reports/2014.pdf.

Siagian, F.T., Tresnaningsih, E. 2011. The impact of independent directors and independent audit committees on earnings quality reported by Indonesian firms. Asian Review of Accounting, 19(3), 192-207. https://doi.org/10.1108/13217341111185128.

Sumiadji, Chandrarin, G., Subiyantoro, E. 2009. Effect of Audit Quality on Earnings Quality: Evidence from Indonesia Stock Exchange. International Journal of Financial Research, 10(1), 86-97. https://DOI:10.5430/ijfr.v10n1p86.

Teoh, S.H., Wong, T.J. 1993. Perceived auditor quality and earnings response co-efficient. American Accounting Association. The Accounting Review, 68(2), 346-366. https://www.jstor.org/stable/248405.

Teoh, S.H., Wong, T.J. 1993. Perceived Earnings Auditor Response Quality and the 
Coefficient. The Accounting Review, 68(2), 346-366.

Tyokoso, G.M., Sabari, M.H., Dogarawa, A.B., Ibrahim, H. 2016. Effect of Audit Quality on Earnings Management of Listed Oil Marketing Companies in Nigeria. Nigerian Journal of Accounting Research, 12(1), 65-96. http://dx.doi.org/10.2139/ssrn.3492016.

Ugwunta, D., Ugwuanyi, B., Ngwa, C. 2018. Effect of audit quality on market price of firms listed on the Nigerian stock market. Journal of Accounting and Taxation, 10(6), 6170.

Wang, C.C., Kung, F.H., Lin, K.H. 2014. Does audit firm Size Contribute to audit quality? Evidence from two emerging markets. Corporate Ownership and Control, 11(2), 96107. https://doi.org/10.22495/cocv11i2p8.

Wijaya, A. 2020. The Effect of Audit Quality on Firm Value: A Case in Indonesian Manufacturing. Journal of Accounting, Finance and Auditing Studies, 6(1), 1-15.

Wijesinghea, M.R.P., Kehelwalatennab, S. 2017. The Impact of Earnings Quality on the Stock Returns of Listed Manufacturing Companies in the Colombo Stock Exchange. Colombo Business Journal, 8(2), 68-89.

Wysocki, P. 2005. Assessing earnings and accruals quality: U.S. and international evidence. Working paper. MIT Sloan School of Management.

Zakaria, N.B., Daud, D. 2013. Does Big 4 affect the earnings response coefficient (ERC)? Evidence from Malaysia. Journal of Modern Accounting and Auditing, 9(9), 12041215.

Zgarni, I., Hlioui, K., Zehri, F. 2016. Effective audit committee, audit quality and earnings management: Evidence from Tunisia. Journal of Accounting in Emerging Economies, 6(2), 138-155. https://doi.org/10.1108/JAEE-09-2013-0048. 